\title{
EFFECT OF OVARIECTOMY AND CONSTANT DARK ON THE WEIGHT OF REPRODUCTIVE AND CERTAIN OTHER ORGANS IN THE FEMALE VOLE, MICROTUS MONTANUS
}

\author{
MARY K. VAUGHAN,* G. M. VAUGHAN† AND R. J. REITER \\ Department of Anatomy, University of Rochester, \\ School of Medicine and Dentistry, Rochester, New York 14620, U.S.A.
}

(Received 7th December 1971)

\begin{abstract}
Summary. Post-partum oestrus occurred in four out of the eight females mated to produce young for this study of Microtus montanus. The sex ratio of the offspring was 2.5 females to 1 male. The female young were kept in diurnal lighting until the age of 30 to 35 days, when a 2-month constant dark period was begun to simulate an intensification of the natural waning photoperiod experienced by voles born in the autumn. Autopsy at the end of the dark period showed that deprivation of light repressed body weight and the absolute weights of ovaries, uterus, adrenals, Harderian glands and, to a lesser extent, kidneys. Both constant dark and ovariectomy in diurnal lighting inhibited thymic involution. The results provide indirect evidence that some of the influence of constant dark is mediated through the pineal gland.
\end{abstract}

\section{INTRODUCTION}

Photoperiod is an important environmental cue to the reproductive activity of microtine rodents. According to Clarke \& Forsyth (1964), during the winter or under simulated 'winter light' conditions in the laboratory $(6 \mathrm{hr}$ light/18 hr dark), reproductive and accessory reproductive organs of both male and female Microtus agrestis are in a regressed state and breeding is rare. Peak breeding activity occurs in the summer. Similarly, Microtus ochrogaster (Benton, 1955), Microtus californicus (Greenwald, 1956) and Microtus montanus (Pinter \& Negus, 1965) are seasonal breeders in the wild, with peak breeding activity in late winter and spring and a minor reproductive period in autumn. With the onset of winter, involution of the gonads and accessory organs occurs and the autumn breeders are referred to as 'regressed' voles (Clarke \& Kennedy, 1967). Young born in the autumn do not attain adulthood or sexual maturity before the onset

\footnotetext{
* Present address: Section on Physiological Controls, Laboratory of Biomedical Sciences, National Institute of Child Health and Human Development, Bethesda, Maryland 20014, U.S.A.

$\dagger$ Present address: Clinical Investigation Section, Biomedical Laboratory, Edgewood Arsenal, Maryland 21010, U.S.A.
} 
of winter and are classified as 'inhibited' animals, i.e. those whose sexual development is not completed in the season of birth.

The present study investigates the action of a constant dark period begun in early adulthood on the reproductive, and certain non-reproductive, organs in female voles born during the autumn months of October and November.

\section{MATERIALS AND METHODS}

Eight male-female pairs of voles were housed in plastic cages with sawdust and cotton supplied for bedding. The animals were maintained under controlled conditions of light (18 hr light $/ 6 \mathrm{hr}$ dark) and allowed free access to rabbit pellets and water. Males remained with their respective female partners during pregnancy, parturition and lactation. Cages were checked daily for the appearance of new litters which were then counted and sexed. Weaning was accomplished 20 to 21 days after birth. The pairs of animals were left together for 18 weeks.

Female offspring, 30 to 35 days of age, were randomized in relation to their litter of origin. Each experimental group was housed in one large $(60 \times 25 \times$ $15 \mathrm{~cm}$ ) opaque plastic cage with a wire top. Ovariectomy was performed under ether anaesthesia. Thirteen ovariectomized voles and eleven controls were placed in diurnal lighting (18 hr light $/ 6 \mathrm{hr}$ dark). A group of nine intact 30- to 35-day-old females were placed in constant dark. All animals were killed 2 months later. The ovaries, uterus, adrenals, thymus, Harderian glands and kidneys were dissected out, cleaned and weighed to the nearest $0.1 \mathrm{mg}$ on a torsion balance. Results were analysed using the Student $t$ test. Harderian glands were included because of a report (Vlahakes \& Wurtman, 1972) which gave evidence that the enzyme, hydroxyindole-O-methyl transferase (HIOMT) can be localized within these organs in the rat. In mammals, HIOMT was previously found only in the pineal gland, where it catalyses the final step in the biosynthesis of the antigonadotrophic substance, melatonin, under the influence of environmental lighting (Wurtman, Axelrod, Ghu \& Fischer, 1964). Kidneys were included as organs not known to be under the specific control of pituitary trophic hormones.

\section{RESULTS}

Table 1 shows the results of the paired matings of Microtus montanus carried out in order to obtain young for the experiments involving ovariectomy and constant dark. Post-partum oestrus occurred in four of the eight mothers, as shown by the appearance of a new litter 21 to 23 days later. A greater proportion of the offspring were females, the sex ratio being approximately 2.5 to 1 .

Absolute weights of adrenals and Harderian glands were significantly increased in the ovariectomized group. Subjection of the female voles to a constant dark period during their rapid growth phase inhibited body weight gain when this was compared with that of voles maintained in diurnal lighting conditions. In the constant dark group, the absolute weights of the ovaries and uterus were significantly depressed, as were those of the adrenals, Harderian 
Table 1. Offspring litter size and sex ratio of pairs of Microtus montanus maintained under diurnal lighting conditions

\begin{tabular}{c|c|c|c|c}
\hline Pair no. & $\begin{array}{c}\text { No. of } \\
\text { litters }\end{array}$ & $\begin{array}{c}\text { No. of } \\
\text { males }\end{array}$ & $\begin{array}{c}\text { No. of } \\
\text { females }\end{array}$ & Total \\
\hline 1 & - & - & - & - \\
$2^{*}$ & 6 & 4 & 19 & 23 \\
3 & 3 & 5 & 6 & 11 \\
$4^{*}$ & 5 & 11 & 21 & 32 \\
$5^{*}$ & 5 & 2 & 14 & 16 \\
6 & 3 & 3 & 9 & 12 \\
$7^{*}$ & 7 & 15 & 27 & 42 \\
8 & 2 & 0 & 5 & 5 \\
Total & 31 & 40 & 101 & 141 \\
\hline
\end{tabular}

Diurnal lighting - $18 \mathrm{hr}$ light $/ 6 \mathrm{hr}$ dark.

* Post-partum oestrus.

glands and kidneys. Though not statistically significant, a decrease also occurred in the relative weights of all these organs, with the exception of the kidneys which had slightly increased relative weights. This is interpreted to signify that decreased organ weight (other than for kidneys) in the constant dark group was not merely secondary to decreased body weight. In both the castrated and the constant dark group, significantly elevated thymus weights (absolute and relative) indicated inhibition of thymic involution (Table 2).

Table 2. Effect of ovariectomy and constant dark on body weight and organ weights in female voles, Microtus montanus

\begin{tabular}{|c|c|c|c|c|c|c|}
\hline & \multicolumn{4}{|c|}{ Diurnal lighting } & \multicolumn{2}{|c|}{ Constant dark (9) } \\
\hline & \multicolumn{2}{|c|}{$\begin{array}{c}\text { Controls } \\
m g \quad \begin{array}{ll}m g / 100 g \\
\text { body } w t\end{array}\end{array}$} & \multicolumn{2}{|c|}{$\begin{array}{l}\text { Ovariectomy }(13) \\
m g \quad \begin{array}{ll}m g / 100 g \\
\text { body wt }\end{array}\end{array}$} & $m g$ & $\begin{array}{c}m g / 100 g \\
b o d y w t\end{array}$ \\
\hline Thymus & $\begin{array}{r}24 \cdot 4 \\
\pm 3 \cdot 3\end{array}$ & $\begin{array}{r}89.9 \\
\pm 9.9\end{array}$ & $\begin{array}{l}37 \cdot 9 * \\
\pm 5 \cdot 4\end{array}$ & $\begin{array}{l}122 \cdot 5^{*} \\
\pm 11 \cdot 1\end{array}$ & $\begin{array}{c}38.5^{*} \\
\pm 3.7\end{array}$ & $\begin{array}{l}195 \cdot 8^{*} \\
\pm 18 \cdot 6\end{array}$ \\
\hline Adrenal & $\begin{array}{r}8.6 \\
\pm 0.7\end{array}$ & $\begin{array}{r}32.4 \\
\pm 1.9\end{array}$ & $\begin{array}{l}14 \cdot 2 * \\
\pm 2 \cdot 4\end{array}$ & $\begin{array}{r}48 \cdot 0 \\
\pm 7 \cdot 3\end{array}$ & $\begin{array}{l}\quad 6 \cdot 2 * * \\
\pm 0.5\end{array}$ & $\begin{array}{r}31 \cdot 6 \\
\pm 2 \cdot 1\end{array}$ \\
\hline Pituitary & $\begin{array}{r}0.97 \\
\pm 0.09\end{array}$ & $\begin{array}{r}3.6 \\
\pm 0.4\end{array}$ & $\begin{array}{r}1.27 \\
\pm 0.20\end{array}$ & $\begin{array}{r}4 \cdot 3 \\
\pm 0.6\end{array}$ & $\begin{array}{r}0.72 \\
\pm 0.11\end{array}$ & $\begin{array}{r}3.7 \\
\pm 0.5\end{array}$ \\
\hline Harderian gland & $\begin{array}{r}40 \cdot 8 \\
\pm 1.9\end{array}$ & $\begin{array}{r}155.2 \\
\pm 6.7\end{array}$ & $\begin{array}{l}46 \cdot 0^{* * *} \\
\pm 2 \cdot 7\end{array}$ & $\begin{array}{r}154.9 \\
\pm 6.8\end{array}$ & $\begin{array}{l}27 \cdot 4^{* * *} \\
\pm 2 \cdot 5\end{array}$ & $\begin{array}{l}138.8 \\
\pm 0.2\end{array}$ \\
\hline Kidney & $\begin{array}{l}126.8 \\
\pm 6.1\end{array}$ & $\begin{array}{r}479 \cdot 9 \\
\pm 16.3\end{array}$ & $\begin{array}{r}147 \cdot 0 \\
\pm 7 \cdot 1\end{array}$ & $\begin{array}{r}498 \cdot 3 \\
\pm 15 \cdot 2\end{array}$ & $\begin{array}{l}104 \cdot 2 * * \\
\pm 4 \cdot 2\end{array}$ & $\begin{array}{r}533.8 \\
\pm 17.8\end{array}$ \\
\hline Ovary & $\begin{array}{r}3.1 \\
\pm 0.2\end{array}$ & $\begin{array}{r}12.0 \\
\pm 1.0\end{array}$ & 二 & - & $\begin{aligned} & 2 \cdot 1^{* *} \\
\pm & 0 \cdot 1\end{aligned}$ & $\begin{array}{r}10.7 \\
\pm 0.9\end{array}$ \\
\hline Uterus & $\begin{array}{r}20 \cdot 2 \\
\pm 1 \cdot 3\end{array}$ & $\begin{array}{r}77 \cdot 2 \\
\pm 5 \cdot 7\end{array}$ & $=$ & - & $\begin{array}{l}13 \cdot 3 * * \\
\pm 1 \cdot 4\end{array}$ & $\begin{array}{r}68.3 \\
\pm 6 \cdot 8\end{array}$ \\
\hline Body weight (g) & $\begin{array}{r}26 \cdot 6 \\
\pm 1.5\end{array}$ & $=$ & $\begin{array}{r}29.7 \\
\pm 1.6\end{array}$ & 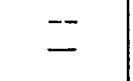 & $\begin{array}{c}19-6^{*} \\
\pm 0 \cdot 6\end{array}$ & $=$ \\
\hline
\end{tabular}

Results are expressed as means \pm S.E. For paired organs, both were weighed together. Numbers in parentheses indicate the number of voles/group.

$* P<0.001$ versus Controls; ** $P<0.01$ versus Controls (Student's $t$ test). 


\section{DISGUSSION}

In obtaining young voles for these experiments, the mating of adult pairs of Microtus montanus resulted in certain findings which deserve separate comment. The occurrence of a fertile post-partum oestrus in the females confirms the similar observation in this species by Negus \& Pinter (1966). The large proportion of female young (101 females out of 141 young) observed in this study is not explained. Reports of deviations from a $50 \%$ female sex ratio are not uncommon in rodents (Mannville, 1956; Kalela \& Oksala, 1966; Terrmann \& Sassaman, 1967; Crawley, 1970). It is of interest that not all genotypes of Microtus ochrogaster produce offspring in a 1:1 sex ratio. Crosses involving one replica (out of a possible four) of the rare transferrin allele $\operatorname{Tf}^{\mathrm{F}}$ produce the greatest percentage of female offspring, while crosses involving three or four of the $\mathrm{Tf}^{\mathbf{F}}$ alleles produce the greatest percentage of males (Myers \& Krebs, 1971).

Since darkness stimulates the pineal gland to produce the antigonadotrophin, melatonin, in the rat (Wurtman, 1967), and pinealectomy in hamsters prevents the gonadal involution due to blinding or constant dark (Hoffman \& Reiter, 1965), it is possible that the effects of darkness observed in the present study with voles were also mediated through the pineal gland. Evidence for this is the observation that both ovariectomy and constant dark inhibited thymic involution, suggesting that constant dark restricted ovarian secretion of thymolytic steroids. Androgens and oestrogens have a thymolytic action (Cosma, 1959). The pineal gland has been implicated in control of the thymus, since Vaughan (1971) found that in male mice pinealectomy permitted greater gonadal inhibition of thymic involution. In the present study, mediation of the thymic response by adrenal suppression in constant dark was not excluded, although ovariectomy inhibited thymic involution in spite of increased adrenal weight.

The body growth of voles was suppressed by constant dark. The pineal also appears to be implicated in this response, since body growth and pituitary level of growth hormone were decreased in rats by blinding but restored toward normal in blinded-pinealectomized animals (Sorrentino, Reiter \& Schalch, 1971).

Although the Harderian gland of the rat is adjacent to the eye, contains porphyrin pigments, undergoes changes in weight in response to environmental lighting (Reiter \& Klein, 1971) and is similar to the pineal gland in its melatonin-forming capacity (Vlahakes \& Wurtman, 1972), its rôle in mediating endocrine responses to light is not established. The inhibition of Harderian gland growth in darkness and enhancement of its growth after ovariectomy observed in the present study seems to indicate lack of a direct single effect of this organ on the thymus of the vole under these conditions. The similarity of Harderian and adrenal gland response to ovariectomy and constant dark is merely suggestive of a functional relationship between these organs.

In order to assess the possible importance of the pineal gland in controlling the reproductive organs of Microtus montanus, twenty voles were pinealectomized and ten were sham pinealectomized. Sham pinealectomy included the routine removal of a small disc of bone at the bregma by use of a dental drill with a 
special circular bit, and disruption of the underlying confluence of sinuses, but without extirpation of the pineal gland. Although none of the sham-pinealectomized group exhibited any noticeable abnormality, fifteen out of the twenty pinealectomized voles died within $3 \mathrm{hr}$ of the operation, and two died later. Close observation of five of those which died early disclosed marked hyperpnoea followed by opisthotonic tetany and interspersed clonic movements before death. Although the main purpose of pinealectomy was not accomplished, these results were quite striking in their resemblance to a similar phenomenon observed in this laboratory in the rat (Reiter, Sorrentino \& Hoffman, 1972). Pinealectomy of young thyroidectomized-and-parathyroidectomized animals always led to tetanic-like convulsions and frequently death within $8 \mathrm{hr}$ of pinealectomy, whereas no rats, from which only the thyroid and parathyroid glands had been removed, convulsed or died. The mechanism whereby pinealectomy influences brain activity (even without prior thyroidectomy-and-parathyroidectomy in the vole) is unknown at present.

\section{ACKNOWLEDGMENT}

This work was supported by USPHS Grant AD-02937. One of us, R.J.R., was a USPHS Career Development Awardee. We thank Dr Norman Negus and Dr Aelito Pinter for their gift of the breeding stock of voles.

\section{REFERENCES}

Benton, A. H. (1955) Observations on the life history of the northern pine mouse. 7. Mammal. 36, 52. Glarke, J. R. \& Forsytr, I. A. (1964) Seasonal changes in the gonads and accessory organs of the vole (Microtus agrestis). Gen. $\mathcal{E}$ compar. Endocr. 4, 233.

Clarke, J. R. \& KenNedy, J. P. (1967) Effect of light and temperature upon gonad activity in the vole (Microtus agrestis). Gen. \& compar. Endocr. 8, 474.

Cosma, J. (1959) Physiologie et physiopathologie du thymus. G. Doin \& Co., Paris.

Crawley, M. C. (1970) Some population dynamics of the bank vole Clerthrionomys glarealus and the wood mouse Apodemus sylvaticus in mixed woodland. F. Zool., Lond. 160, 71.

Greenwald, G. (1956) The reproductive cycle of the field mouse, Microtus californicus. F. Mammal. 37, 213.

Hoffman, R. A. \& Rerter, R. J. (1965) Pineal gland: influence on gonads of male hamsters. Science, N.Y. 148, 1609.

Kalela, O. \& Oksala, T. (1966) Sex ratio in the wood lemming, Myopus schisticolor (Lilljeg.), in nature and in captivity. Annls Univ. turku. Ser. A. II, Biol.-Geogr. 37, 5.

Mannville, R. H. (1956) Unusual sex ratio in Peromyscus. 7. Mammal. 37, 122.

MYers, J. H. \& KREBS, C. J. (1971) Sex ratios in open and enclosed vole populations: demographic implications. Am. Nat. 105, 325.

Negus, N. G. \& Pinter, A. J. (1966) Reproductive responses of Microtus montanus to plants and plant extracts in the diet. F. Mammal. 47, 596.

Pinter, A. J. \& Negus, N. G. (1965) Effects of nutrition and photoperiod on reproductive physiology of Microtus montanus. Am. F. Physiol. 208, 633.

REITER, R. J. \& KLEIN, D. C. (1971) Observations on the pineal gland, the Harderian gland, the retina, and the reproductive organs of adult female rats exposed to continuous light. $\mathcal{F}$. Endocr. 51, 117.

Retrer, R. J., Sorrentino, S. \& Hoffman, R. A. (1972) Muscular spasms and death in thyroparathyroidectomized rats subjected to pinealectomy. Life Sci. 11, 123.

Sorrentino, S., Reiter, R. J. \& Schalch, D. S. (1971) Pineal regulation of growth hormone synthesis and release in blinded and blinded-anosmic male rats. Neuroendocrinology, 7, 210.

Terrmann, C. R. \& Sassaman, J. F. (1967) Sex ratio in deer mouse populations. F. Mammal. 48, 589.

VAUGHAN, M. K. (1971) Effects on accessory organs, adrenals, and thymus after pinealectomy in male mice. Anat. Rec. 169, 466. 
Vlahakes, G. J. \& WURTMAN, R. J. (1972) A $\mathrm{Mg}^{2}+$ dependent hydroxyindole O-methyltransferase in rat Harderian gland. Biochim. biophys. Acta, 261, 194.

Wurtman, R. J. (1967) Effects of light and visual stimuli on endocrine function. In: Neuroendocrinology, Vol. II, p. 19. Eds. I. Martini and W. F. Ganong. Academic Press, New Xork.

Wurtman, R. J., Axelrod, J., Chu, E. W. \& Fischer, J. E. (1964) Mediation of some effects of illumination on the rat estrous cycle by the sympathetic nervous system. Endocrinology, 75, 266. 